\title{
Some Account of the British Military Hospitals of World War I at Etaples, in the orbit of Sir Almroth Wright.
}

\author{
EW Meynell \\ $M D$
}

Haven House, St Margaret's Bay, Dover CT15 6DR

SUMMARY: A group of British Military Hospitals was established between 1915 and 1918 along the estuary of the River Canche on the northern French coast. Their positions, now obliterated, can be identified from a plan of the time. With the growing realisation of the importance of bacteriology in the treatment of wound infection, the laboratory of Sir Almroth Wright in neighbouring Boulogne-sur-mer had a strong local influence.

\section{Introduction}

The German army invaded Belgium on the 4th of August 1914 and by the autumn was approaching the English Channel. With the first Battle of Ypres in October in which there were nearly 100,000 British casualties, the French port of Boulogne-sur-mer was transformed into an important British military hospital base (1) and by degrees numbers of hospitals were set up in the surrounding country, notably at Etaples and Camiers, along the estuary of the River Canche some 15 miles SW of Boulogne. Three of the Etaples hospitals have left records of their histories, one Imperial Service Hospital, the No.26 General (2), and two lavishly equipped Voluntary Hospitals, the No.6 BRCS, or Liverpool Merchants', Hospital $(3,4)$ and the St John Ambulance Brigade Hospital $(5,6)$.

\section{The importance assigned to bacteriology}

The War of 1914-1918 was marked by growing emphasis on pathological investigation of wound infection and the hospitals at Etaples, particularly the $\mathrm{St}$ John Ambulance Brigade Hospital, were well aware that the celebrated bacteriologist, Sir Almroth Wright, was at the 13th General Hospital in the Casino in Boulogne. The importance of bacteriology was clear to the War Office from the beginning of the war, when on 3 October 1914 it appointed Colonel Sir William Leishman as 'Advisor in Pathology' attached to the Director of Medical Services of the British Expeditionary Force (7). Leishman's task was to recruit personnel and to superintend the work of the hospital laboratories; however, Wright's laboratory was not under his control (8). Wright had come to France with the British Expeditionary Force at the direct suggestion of Lieutenant General Sir Alfred Keogh, Director General of the Army Medical Services at the War Office. Lord Kitchener had been strongly against having any bacteriologists - 'They are no good' -, so he had come out as a Consultant Physician (9). His staff included Alexander Fleming, later to discover penicillin, Leonard Colebrook, remembered for his work on streptococcal infections, John Freeman and Parry Morgan, all previously assistants in his Vaccine Department at St Mary's Hospital in London (10). The American neurosurgeon, Harvey Cushing, who came to France with the Harvard Voluntary Medical Unit in 1917, was constantly present (11). The Harvard Unit had initially been allocated part of a hospital in Camiers but, because the hospital had had problems with drainage due to the lie of the land, the Unit was subsequently invited to replace the British staff at No. 13 General Hospital in the Boulogne Casino where Wright's laboratory was situated (12). The Danish bacteriologist, Georges Dreyer, was gazetted honorary Captain in the RAMC to enable him to join a neighbouring hospital to supplement Wright' investigations into typhoid vaccination by the addition of vaccines against paratyphoids $A$ and $B$ (13).

\section{The wartime achievements of Sir Almroth Wright}

Sir Almroth Wright is known to have regarded th development of bacterial vaccines as his most importan work (14), but looking back, it can be argued that his greatest achievements really lay in the stimulus he gave to wartime bacteriology and in his efforts to make the War Office improve the organisation of medical services in France. Statistical analysis of Wright's method of immunisation against typhoid fever by the injection of killed suspensions of typhoid bacilli showed that it was far less effective than he assumed (15) and his faith in 'therapeutic vaccination' (treatment of established infections by injection of killed suspensions of the bacterial strain isolated from the patient) was quite unjustified. However, with the help of the simple experimental techniques he had earlier devised (16), whose economy in the use of materials was so well suited to a wartime laboratory, he conveyed clearly and unremittingly to others an understanding of the essential nature of war wounds, infected from the outset by every sort of microbe driven in by the projectile. 'We are wont to classify the patients in our military hospitals into sick and wounded. In reality, all, or nearly all, are suffering from bacterial infections' (17). He was repeatedly to stress that a wounded man under a lengthy treatment should not be 'hustled' to a hospital in England (18), because the base hospitals in France were rarely full; the opinions of the medical man should be followed instead of those of the hospital administrator; methods of 


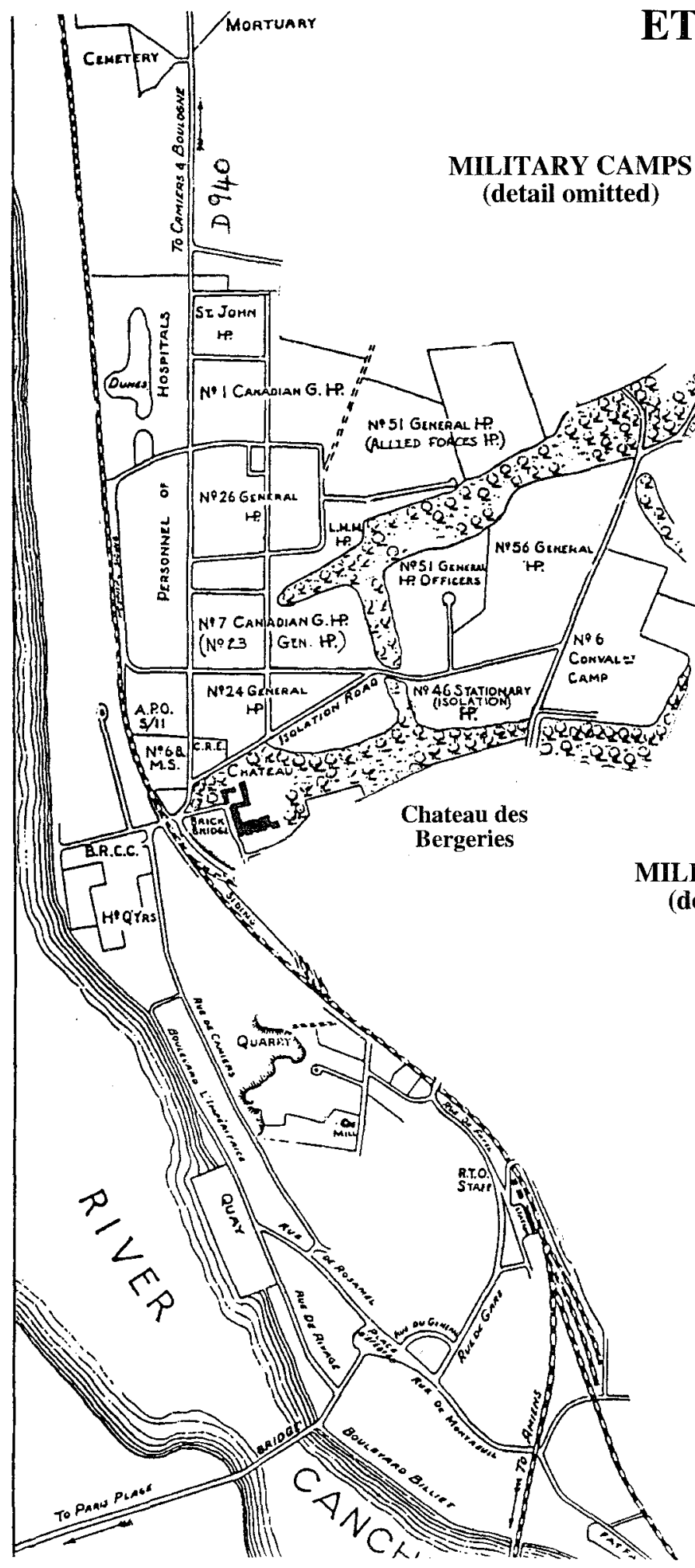

ETAPLES 1917 
treatment should be standardised under advice from a medical intelligence department staffed by scientists (9); and medical officers should be given organised instruction, since most had been recruited from civilian life and were therefore faced with unfamiliar problems. The ultimate arrangements in France (19) did largely conform to what Wright advocated although his advice was by no means always gratefully acknowledged (18). The inexperience of the medical officers was to some extent compensated for by the existence of medical societies, of which the Boulogne Medical Society (11) was one and the Etaples Medical Society another (20).

\section{Table 1}

Military Hospitals at Etaples

1. No. 24 General Hospital, 21 June 1915 until 4 November 1919. Incorporated Villa Tino Hospital 3 December 1915-13 May 1919 and Sick Sisters Hospital 12 April 1917-1 July 1919. Admitted German prisoners. No. 28 Etaples Isolation Hospital became No. 24 General Hospital Isolation Block 27 July 1915-March 1917, before becoming No. 46 Stationary Hospital.

2. No. 46 Stationary Hospital.

3. No. 26 General Hospital, 21 June 1915 until 17 July 1919.

4. No. 23 General Hospital, June 1915 until 15 November 1916. Staffed by Chicago Voluntary Medical Unit, 4 July 1915. Retitled No. 7 Canadian General Hospital, 15 November 1916.

5. No. 6 BRCS, or Liverpool Merchants' Hospital, 4 July 1915 until 1 June 1918. Located 19 April 1915-3 July 1915 in the Grand Hotel, Paris-Plage.

6. St John Ambulance Brigade Hospital, 22 July 1915 until 31 May 1918. Restarted in Trouville, October 1918-February 1919.

7. No. 51 General Hospital, 10 August 1915 until 29 June 1918. Also known as Allied Forces Base Hospital, it began in Hotel Christol, Boulogne, on 23 October 1914 with an annexe in Etaples.

8. No. 1 Canadian General.

9. No. 56 General Hospital, 23 May 1917 until 26 April 1919. Also known as 2nd Southern Territorial Force Hospital because it was formed from the 2 nd Southern Territorial Force at Bristol.

Observation Hut, June 1917 until the Air Raids of May-June 1918, when it moved to Rouen.

Electro-therapeutic Hut attached to No. 6 Convalescent Camp, 1 October 1917.

Red Cross Ambulance Convoy, with dormitories, mess huts and workshops.

\section{The hospitals}

The British Base Hospitals at Etaples (Table 1) were established from June 1915 along the road and railway line bordering the estuary of the River Canche $(1,19,21,22,23)$. A railway siding at Etaples could accommodate two ambulance trains either arriving with wounded from the Front or leaving for Boulogne with hospital patients to be evacuated to England (1). The sites where the hospitals stood are known from a plan of 1917 (Fig 1), but nowadays all traces of their presence are obliterated and the only surviving reminder of the war is the British Military Cemetery, one of the great war monuments of Sir Edwin Lutyens.
No.26 General Hospital (2) was situated on the eastern, or inland, side of the road. On the side bordering the estuary, between the road and the main railway line to Boulogne, were the quarters for the staff who were continually disturbed by trains passing every 10 minutes or so, day and night. The land is chalk covered with drifted sand and, although the topsoil had been largely stabilised by the planting of grasses after 1750 (24) and of pines after 1830 (25), sand was still able to cause difficulties when it was driven by the prevailing southwest winds into wards and operating theatres. Gardening was important, not only to aid morale but to control and sand, in particular by the making of cinder paths and laying down of turf (whose removal from the site of one hospital to another was strictly regulated). No.26 hospital consisted of a main building of corrugated iron, divided into four surgical wards of 23 beds each, two operating theatres and an X-ray room, with kitchen, administrative block, laboratory, stores, dispensary, latrines and wash houses in outbuildings of similar construction. There were 31 wards of 27 beds in free-standing wooden huts $120 \mathrm{ft}$ long with tarred canvas roofs. They were barrack huts only $15 \mathrm{ft}$ wide and could accommodate only a single row of 21 beds, the extra 6 being placed lengthwise along the opposite wall (26). Eight of the wards were for skin conditions and one for mental cases, for No.26 General Hospital had been selected for the reception of skin diseases and the insane. Heating was by stoves, two to a ward. Electricity and a piped water supply came across the river from Paris Plage, with stand-pipes between the lines of huts and taps in the theatre block, kitchens, dispensary and laboratory. The latrines and bath houses were at some distance from the wards. There was no drainage system, solid material was incinerated and liquids, of whatever source, were run through gullies into soak pits driven 7-8ft into the chalk and boarded to keep out the sand. These had constantly to be re-dug.

The history of the voluntary No.6 BRCS or Liverpool Merchants' Hospital, constructed and equipped from funds raised by members of the Liverpool Chamber of Commerce and staffed by volunteers from Liverpool, has been published in detail by Hayward (3) and by Chavasse et al (4). Intended as a mobile hospital, it was specially designed to be easily and quickly dismantled and reassembled.

The St John Ambulance Brigade Hospital $(5,6)$, was 'considered by all who knew it to be the best designed and equipped military hospital in France' (5). It was established through an arrangement with the War Office on 2 March 1915 by which the Order of St John was to supply, equip and maintain a Base Hutted Hospital on land which the War Office would provide. The War Office was also to provide rations, hospital clothing, and clothing on discharge if the patient's original uniform was not fit to be used. With 520 beds, it was the largest of the voluntary hospitals serving with the British Expeditionary Force in France (1). There were 17 medical and surgical 
officers, one dental surgeon, 55 nurses, 23 VADs and 141 orderlies. The Commanding Officer was paid by the War Office, the remaining staff, recruited by the Commanding Officer, were paid by the St John Ambulance Brigade. The hospital had 16 wards of 30 , and 2 wards of 20 beds, in specially commissioned huts (27) arranged in two lines on either side of the administrative offices and connected by covered ways. Although cameras were initially forbidden, permission was given for a firm of commercial photographers to record its much admired architectural aspects. Its high degree of efficiency was considered to be due to its having a permanent staff. On the other hand, since it admitted only severely wounded cases, the death rate was high (19). It had its own oil-fired electricity generator, and plants for making ice and soda water. There were two operating theatres and an anaesthetic room, an X-ray department where almost half the wounded men were $X$-rayed on admission using a technique developed to show the position of foreign bodies in three dimensions (20), an electro-cardiograph (the only one in France at the time), and a pathological laboratory frequently visited by members of Wright's laboratory in Boulogne. Visits from Colebrook were especially welcome (Personal communication from the author's father, John McCloy: Who Was Who, 19401950).

\section{Opposing views on wound disinfection}

Wright and his followers advocated a "physiological method' of wound treatment, in which the wound was irrigated with a hypertonic salt solution to encourage the release of fluid 'charged with phagocytes' (17). By 1916, Wright had begun a vigorous campaign against the use of antiseptics, which according to him would kill not only the bacteria but also these phagocytes. Experiments in his Boulogne laboratory, which seem initially to have been mainly concerned with production of serum agglutinins after vaccination, had moved on by then to examining the efficiency of antiseptics in the presence of serum (28).

Wright's antagonism towards the use of antiseptics excited considerable controversy (29) and, of the Etaples hospitals, No.26 General Hospital, in particular, did not share his belief in the 'physiological method' of wound treatment. A ward of No.26 General Hospital had been allocated to Surgeon-General Sir George Makins, with 2 surgeons and a bacteriologist, for study of treatment by the so-called 'Carrel-Dakin Method' $(2,19)$, a method consisting of insertion of drainage tubes and irrigation with buffered hypochlorite, or 'Dakin's solution' (30). In June 1917, a special 'Observation Hut', consisting of 2 wards, an operating theatre and a pathological laboratory, was also set up in Etaples under Makins to compare treatment of severe wounds by Carrel-Dakin, Bipp, Dichloramine T, Flavine and simple aseptic methods. Clinical trials suggested that the Carrel-Dakin method was the best (1). But this conclusion was said to have been later abandoned (11).

\section{The end of the Etaples hospitals}

The Etaples hospitals were destroyed by German ai⿱ raids which began on 19 May 1918 and continued until 18 August. There were grave doubts as to the wisdom of having sited large military training camps and hospitals so? close together $(21,26,31,32)$ but it was generally believe承 that the enemy's target was really the railway bridge oves the River Canche. This belief was confirmed when Ef German airman who had been shot down said to hisp

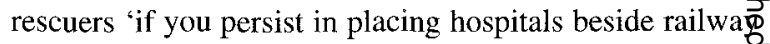
lines, they will continue to be bombed' (33). In the first attack of 19 May, in which 10 or 12 German planes took part, more than 300 patients were killed or wounded an $\Phi$ incendiary bombs were dropped on the town of Etaple (33). Further raids occurred on 27 and 31 May, 28, 29 an 31 June, 1, 25 and $31 \mathrm{July,}$, and 10 August (34). The hospital gardens were dug up for shelters (26). In the rai胥 of 31 May, the St John Hospital was rendered uninhabitable with serious loss of life (6). On 29 Junet No.51 Hospital was bombed (34). The Liverpoo $\Phi$ Merchant's Hospital received no direct hit but nevertheless, decided not to carry on and left Etaples fof Trouville on 1 June $1918(3,4)$.

\section{Acknowledgements}

The author would like to acknowledge with tha被 information received from the RAMC Military Histor Society, Keogh Barracks, Aldershot GU12 5RQ; 年e Western Front Association, 6 Clarendon Rosdeg Cambridge CB2 2BH; the Museum and Library of the Order of St John, St John's Gate, Clerkenwell, Lond EC1M 4DA; Le Centre de Recherche de l'Historial de्pl| Grande Guerre, Château de Peronne, 80201 Peronne; Le ริ Archives Départmentales du Pas-de-Calais, 1 rue du 18

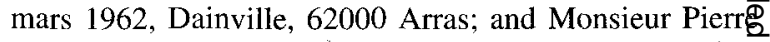
Baudelicque, Société Historique et Culturelle d'Etaples: Courteville-Tubersent, 62630 Etaples. I should also like t9 thank the Institut Géographique National de France for $\mathbb{D}$ Carte Topographique of 1929 and an aerial photograph of. 1947.

\section{REFERENCES}

1. Reports by the Joint War Committee and the Join War Finance Committee of the British Red Cros Society and the Order of St John of Jerusalem i England on Voluntary Aid rendered to the Sick an Wounded at Home and Abroad and to Britis Prisoners of War 1914-1919. London: HMSO, 1921 Part XVI.

2. War Diary of No.26 General Hospital, RAM@ Muniments Collection No 728/2, Wellcome Institut of the History of Medicine.

3. HAYWARD JD. The Liverpool Merchants' Mobil Hospital in France 1915-18. Liverpool: Young, 1919. N

4. Chavasse E, Clayton A. The Liverpool Merchants Mobile Hospital Etaples, 1915-18. Stand-to 1993; 12ర 17. 
5. Ref 1. Appendix VII Memorandum by the Grand Priory of the Order of the Hospital of St John of Jerusalem in England on its separate war work from August 4, 1914 to December 31, 1919.

6. Archives of the Library of the Order of St John, St John's Gate, St John's Lane, Clerkenwell, London EC1M 4DA.

7. MacPherson WG. History of the Great War Based on Official Documents: Pathology. London: HMSO, 1923.

8. Interview with Sir William Leishman. Report on Medical Services in France, Commission on Medical Establishments, to the Secretary of State of War. RAMC Muniments Collection No.1165, Wellcome Institute for the History of Medicine.

9. Interview with Sir Almroth Wright, 8 September 1917. Report, Ref. 8.

10. HARE R. The scientific activities of Alexander Fleming, other than the discovery of penicillin. $\mathrm{Med}$ Hist, 1983; 27: 347-372.

11. Cushing H. From a Surgeon's Journal 1915-1918. London: Constable, 1936.

12. RAMC Muniments Collection No 446/20, Wellcome Institute for the History of Medicine.

13. Dreyer M. Georges Dreyer. A Memoir by his wife. Oxford: Blackwell, 1937.

14. Colebrook L. Almroth Wright, Provocative Doctor and Thinker. London: Heineman, 1954.

15. Papers by K Pearson and AE Wright, $\mathrm{Br}$ Med $J$, 1904; ii:

16. WRIGHT AE. Technique of the Teat and Capillary Glass Tube. London: Constable, 1912.

17. WRIGHT AE. A lecture on the treatment of war wounds. Lancet 1917; i: 939-949.

18. Memorandum from Sir Almroth Wright January 1917, RAMC Muniments Collection No.365/4, Wellcome Institute for the History of Medicine.

19. Report on Medical Services in France, Commission on Medical Establishments, to the Secretary of State for War. RAMC Muniments Collection No.1165, Wellcome Institute for the History of Medicine.
20. CRYMBle PT. Anatomical localisation of a metallic foreign body and reconstruction of its track. BrJ Surg 1916-1917; 4: 234-258. (Read before the Etaples Medical Society, January 1916).

21. Forbes A. Memories and Base Details. London: Hutchinson, 1921.

22. MACPhERSON WG. History of the Great War Based on Official Documents: Medical Services General History. London HMSO, 1921; Vol II: 64-84; Vol III: Appendix.

23. Personal communications from: RAMC Military Historical Society, Western Front Association, and Centre de Recherche de l'Historial de la Grande Guerre, Château de Peronne.

24. Calonne A. Arrondissement de Montreuil-sur-mer. Histoire des Cantons de Compagne-les-Hesdin, Etaples, Hesdin, Hucqueliers, Montreuil-sur-mer. Arras, 1875.

25. Lejeal L. Essai sur la Géographie du Boulonnais. Boulogne, 1899; Vol I.

26. BradFord M. A Hospital Letter-Writer in France. London: Methuen, 1920.

27. From Messrs Humphreys of Knightsbridge.

28. Notebooks of Alexander Fleming. British Library Additional Manuscripts Nos. 56141-56147.

29. WATSON CHEYNE W. On the treatment of wounds in War. Br J Surg, 1915-1916; 3: 427-450.

30. Barling G. The Carrel treatments of wounds. $\mathrm{Br} J$ Surg, 1918; 5: 116-125.

31. LesaGe C. Les Mutins. Etaples: AMME Editions, n.d. Expanded from Alzuson W and FatrLey J. Monocled Mutineer. London: Quartet Books, 1979.

32. BAUDELICQUE P. Histoire d'Etaples des Origines à nos Jours. Etaples: 1995; Vol II.

33. Le Télégramme du Pas de Calais, 2 Juin 1918.

34. Le Télégramme du Pas de Calais, 21 Mai 1919. 